\title{
Effect of Year Wise on Incidence of Mastitis in crossbred, indigenous Cattle and Murrah Buffaloes
}

\author{
S.C. Jingar, Mahendra Singh, Pankaj Lawania, A.K. Roy, Ajesh Kumar, \\ Krishi Vigyan Kendra and Chittorgarh
}

\author{
Maharana Pratap University of Agriculture and Technology, Udaipur, India \\ *Corresponding author
}

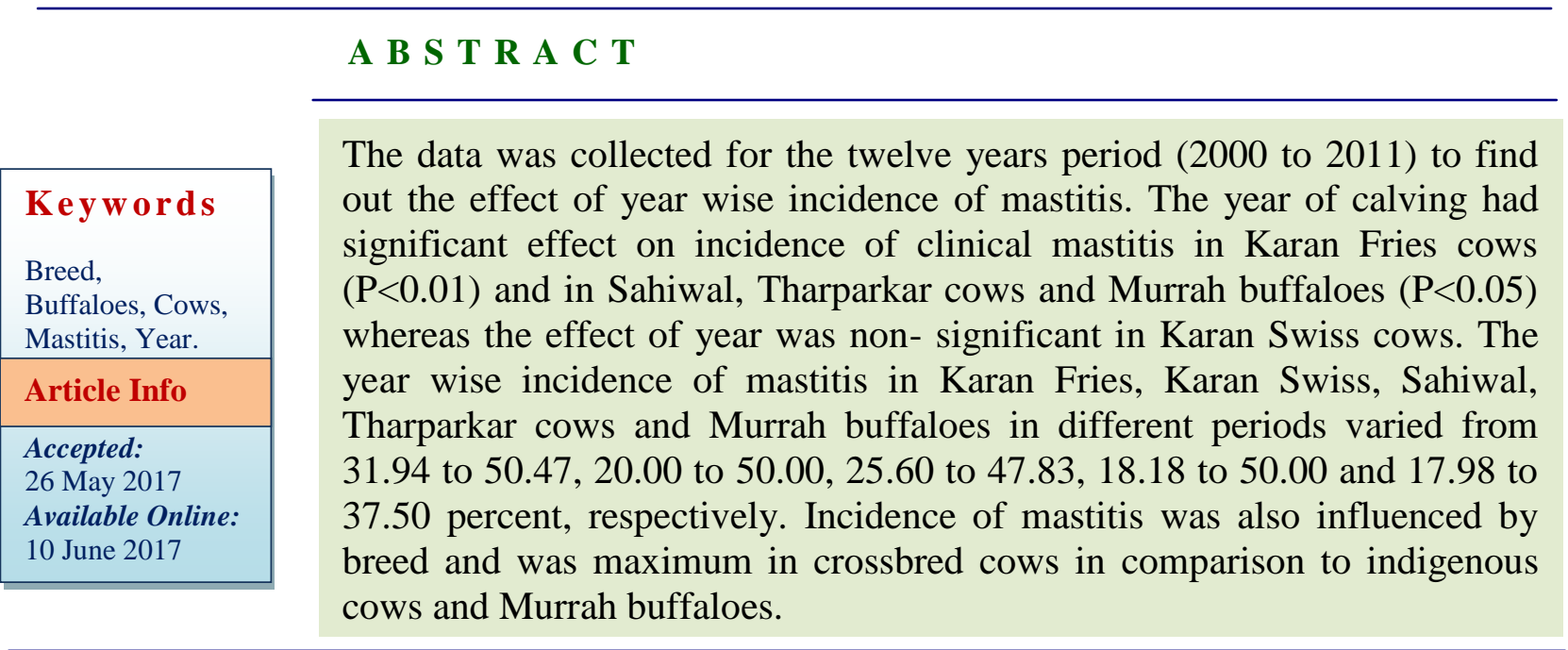

\section{Introduction}

Mastitis in dairy animals is considered one of the costly production diseases and it causes enormous loss to the dairy industry (Bardhan, 2013; Mathew and Menon, 2008). Mastitis, an inflammatory reaction of mammary gland is the most dreaded disease for dairy farmers because of reduced milk production, increased treatment costs, labour, milk discarding following treatment, death and premature culling (Radostits et al., 2007 and Yang et al., 2011).

\section{Materials and Methods}

Data pertaining to 4520 lactations records of Karan Fries (2154), Karan Swiss (292)
Sahiwal (822), Tharparkar cows (160) and Murrah buffaloes (1092) were spread over twelve years (2000-2011) was collected from history sheets, stock registers and health record registers maintained in different sections of the institute (at NDRI Karnal). The climate of the farm is subtropical in nature. The lowest temperature falls to $2^{\circ} \mathrm{C}$ during the winter months, whereas highest temperature goes up to $45^{\circ} \mathrm{C}$ during the summer.

The annual rainfall is about 760 to $960 \mathrm{~mm}$, out of which most of the rainfall is received during the months of July and August. The relative humidity ranges from $41 \%$ to $85 \%$. 
The data was classified as normal and mastitic animals. The incidence of mastitis, data was classified year wise along with codes (1-12), to assess the percent incidence and the effect of year wise incidence on mastitis used chisquare method (Snedecor and Cochran, 1994).

Chi-square $=\Sigma(\mathrm{O}-\mathrm{E})^{2} / \mathrm{E}$

Where,

$\mathrm{O}=$ Observed frequencies; $\mathrm{E}=$ Expected frequencies,

Expected frequencies will be calculated as: $\mathrm{E}_{\mathrm{ij}}$ $=\left(\mathrm{R}_{\mathrm{i}}\right)\left(\mathrm{C}_{\mathrm{j}}\right) / \mathrm{GT}$

Where,

Eij $=$ Expected frequency belong to $i^{\text {th }}$ row and $j^{\text {th }}$ column

$\mathrm{R}_{\mathrm{i} .}=\mathrm{i}^{\text {th }}$ row total; $\mathrm{C}_{\mathrm{j}}=\mathrm{j}^{\text {th }}$ column total; $\mathrm{GT}=$ Grand total

The association between two variables will be studied using Chi-Square statistics.

\section{Results and Discussion}

The year wise overall incidence of mastitis was higher in crossbred cows (37.68\%) followed by Indigenous cows $(33.71 \%)$ and Murrah buffaloes $(26.26 \%)$. The year wise incidence of mastitis in Karan Fries, Karan Swiss, Sahiwal, Tharparkar cows and Murrah buffaloes in different periods varied from 31.94 to $50.47,20.00$ to $50.00,25.60$ to 47.83 , 18.18 to 50.00 and 17.98 to 37.50 percent, respectively. Though the incidence of mastitis varied across different years yet it could not reveal any consistent trend during the different years of study. The incidence of mastitis was higher in Karan Fries cows and 2005 (50.47\%) and lower in 2001(31.94\%), in Karan Swiss cows the incidence was low in $2007(20.00 \%)$ and was more in 2003 (50.00\%) (Table \& Figure).Contrary to this, Murrah buffaloes had lowest incidence of mastitis of $17.98 \%$ in 2008 and highest of $37.50 \%$ in 2005. Tharparkar and Sahiwal cows had lower incidence of mastitis of $12.50 \%$ and $25.00 \%$ in 2008 and 2010 while, higher incidence of $50 \%$ and $47.83 \%$ was observed in 2001\&2002 and 2000. The year of calving had significant effect on incidence of clinical mastitis in Karan Fries cows $(\mathrm{P}<0.01)$ and in Sahiwal, Tharparkar cows and in Murrah buffaloes $(\mathrm{P}<0.05)$, whereas the effect of year was non- significant in Karan Swiss cows.

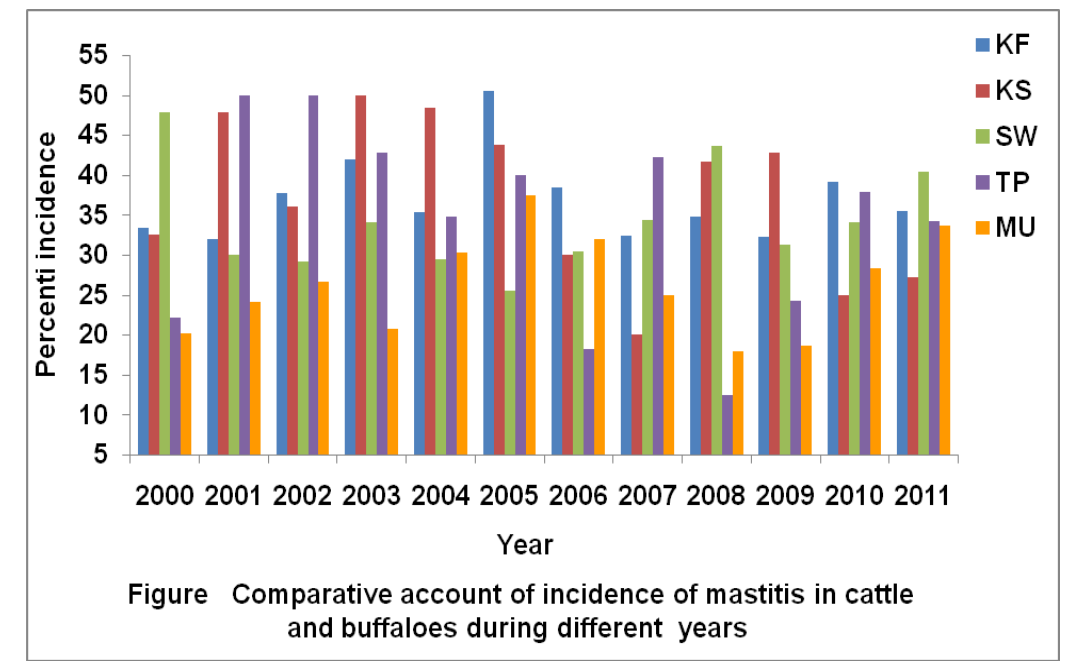


Table.1 Incidence of clinical mastitis (\%) in various breeds of cattle and buffaloes in different years

\begin{tabular}{|c|c|c|c|c|c|c|c|c|c|c|}
\hline \multirow[b]{3}{*}{ Effect } & \multicolumn{10}{|c|}{ Breed } \\
\hline & \multicolumn{2}{|c|}{ Karan Fries Cows } & \multicolumn{2}{|c|}{ Karan Swiss Cows } & \multicolumn{2}{|c|}{ Sahiwal Cows } & \multicolumn{2}{|c|}{ Tharparkar Cows } & \multicolumn{2}{|c|}{ Murrah Buffaloes } \\
\hline & NO. & Mastitis & NO. & Mastitis & NO. & Mastitis & NO. & Mastitis & NO. & Mastitis \\
\hline Overall & 2553 & $36.90(942)$ & 351 & $38.46(135)$ & 1554 & $33.98(528)$ & 323 & $33.44(108)$ & 1470 & $26.26(386)$ \\
\hline \multicolumn{11}{|c|}{ Year } \\
\hline 2000 & 251 & $33.47(84)$ & 46 & $32.61(15)$ & 69 & $47.83(33)$ & 18 & $22.22(04)$ & 159 & $20.13(32)$ \\
\hline 2001 & 191 & $31.94(61)$ & 46 & $47.83(22)$ & 113 & $30.01(34)$ & 18 & $50.00(09)$ & 116 & $24.14(28)$ \\
\hline 2002 & 191 & $37.70(72)$ & 36 & $36.11(13)$ & 120 & $29.17(35)$ & 16 & $50.00(08)$ & 105 & $26.67(28)$ \\
\hline 2003 & 181 & $41.99(76)$ & 40 & $50.00(20)$ & 138 & $34.05(47)$ & 21 & $42.86(09)$ & 106 & $20.75(22)$ \\
\hline 2004 & 212 & $35.38(75)$ & 33 & $48.48(16)$ & 122 & $29.51(36)$ & 23 & $34.78(08)$ & 122 & $30.33(37)$ \\
\hline 2005 & 214 & $50.47(108)$ & 32 & $43.75(14)$ & 125 & $25.60(32)$ & 25 & $40.00(10)$ & 120 & $37.50(45)$ \\
\hline 2006 & 242 & $38.43(93)$ & 30 & $30.00(09)$ & 148 & $30.41(46)$ & 33 & $18.18(06)$ & 153 & $32.03(49)$ \\
\hline 2007 & 216 & $32.41(70)$ & 20 & $20.00(04)$ & 128 & $34.37(44)$ & 45 & $42.22(19)$ & 136 & $25.00(34)$ \\
\hline 2008 & 198 & 34.85 (69) & 12 & $41.67(05)$ & 126 & $43.65(55)$ & 24 & $12.50(03)$ & 89 & $17.98(16)$ \\
\hline 2009 & 229 & $32.31(74)$ & 14 & $42.86(06)$ & 144 & $31.25(45)$ & 33 & $24.24(08)$ & 134 & $18.66(25)$ \\
\hline 2010 & 217 & $39.17(85)$ & 20 & $25.00(05)$ & 158 & $34.081(55)$ & 29 & $37.93(11)$ & 141 & $28.37(40)$ \\
\hline 2011 & 211 & $35.55(75)$ & 22 & $27.27(06)$ & 163 & $40.49(66)$ & 38 & $34.21(13)$ & 89 & $33.71(30)$ \\
\hline
\end{tabular}

NO. =Number of observation; Figures in parentheses indicate the number of observation of mastitic animals 
There was a significant effect of year on mastitis incidence which corroborates the earlier report by who reported a significant effect of year of calving on incidence of clinical mastitis was reported by Chand and Behra (1995) in Karan Fries, Karan Swiss, Sahiwal cows and Murrah buffaloes. However, in this study the effect of year incidence in Karan Swiss cows was non- significant.

On the other hand, Mukherjee, (1993) and Sharma (2010) found a significant effect of year of calving in clinical mastitis in Karan Fries cows whereas, significant effect of year of calving on incidence of mastitis was in Murrah buffaloes (Tomar, 1984; Tomar and Tripathi, 1984). Contrary to the result of present study, Pal (2003), Taraphder (2006), Joshi and Shrestha (1995) and Patil et al., (1995) reported non-significant effect of period of calving in cattle and buffaloes. Climatic variable was not uniform during the different years of study which led to a significant difference in incidence of mastitis during different year of study. From the study it was concluded that buffaloes were more resistance to mastitis as compared to cows. Further, Incidence of mastitis was also influenced was maximum in crossbred cows in comparison to indigenous cows and Murrah buffaloes.

\section{References}

Bardhan, D. 2013. Estimates of economic losses due to clinical mastitis in organized dairy farms, Indian J. Dairy Science. 2(66): 168172.

Chand, P. and Behra, G.D. 1993. Factors influencing occurrence of mastitis genetic and environmental factors. Indian. $J$. Dairy Sci., 48: 271-273.

Joshi, H.D. and Shrestha, K.H. 1995. Study on the prevalence of clinical mastitis in cattle and buffalo under different management system in the western hills of Nepal. Working Lumle Regional Agric. Res. Centre, 4: 64-95.

Mathew, L. and Menon, D. G. 2008. Economic impact of FMD in Chazhoor Panchayath. Veterinary World 1 (1): 5-6.

Mukherjee, K., Tomar, S. S. and Sadana, D. K. 1993. Genetic studies on udder problems in Karan Fries herd. Indian vet. J., 70 (2): 121124.

Pal, 2003. Investigation on health disorders in dairy cattle and buffaloes during pre and postpartum period. Ph.D Thesis submitted to NDRI, Karnal.

Patil, N. A., Harapanahalli M. D., Mulia J. A., Hosmani S. V. and Pugashetti B. K. 1995. Comparative study on prevalence and diagnosis of sub-clinical mastitis in cows and buffaloes. Indian Journal of Dairy Science 48: 478-79.

Radostits, O.M., Gay, C.C., Blood, D.C. and Hinchkliff, K.W. 2000. Veterinary Medicine. 9th edn. ELBS \& Baillier Tindall. 563-618

Sharma P.C., 2010 Genetic evaluation of Karan Fries cows for functional traits. Ph.D. Thesis submitted to N.D.R.I., Karnal, Haryana132001.

Snedecor, G. W. and Cochran, W. G. 1994. Statistical methods. 8th Ed. Iowa State University Press, Ames, USA

Taraphder, S., Tomar, S.S. and Gupta, A.K. 2006. Incidence, inheritance and economics of mastitis in an organized herd of Murrah buffaloes. Indian J. Anim. Sci.,76 (10): 838842.

Tomar S S. 1984. Inheritance of certain threshold characters inbuffaloes. Ph.D. Thesis. Submitted to Kurukshetra University, Kurukshetra, Haryana.

Tomar, S. S. and Tripathi, V.N.1984. Inheritance of udder disorders in Murrah buffaloes. Ind. J. Anim. Genet. And Breed. 6(1-2):19-21.

Yang, F.L, Yang, B.B and Huang, Q.H. 2011. Bovine Mastitis in Subtropical Dairy Farms, 2005-2009. Asian Journal of Animal and Veterinary Advances. (10): 68-72.

\section{How to cite this article:}

Jingar, S.C., Mahendra Singh, Pankaj Lawania, A.K. Roy and Ajesh Kumar. 2017. Effect of Year Wise on Incidence of Mastitis in Crossbred, Indigenous Cattle and Murrah Buffaloes. Int.J.Curr.Microbiol.App.Sci. 6(6): 2725-2728. doi: https://doi.org/10.20546/ijcmas.2017.606.325 